\title{
Može li škola odgojiti što društvo i obitelj ne mogu?
}

\author{
Salezijanska klasična gimnazija s pravom javnosti, Rijeka, 2014., 194 \\ str.
}

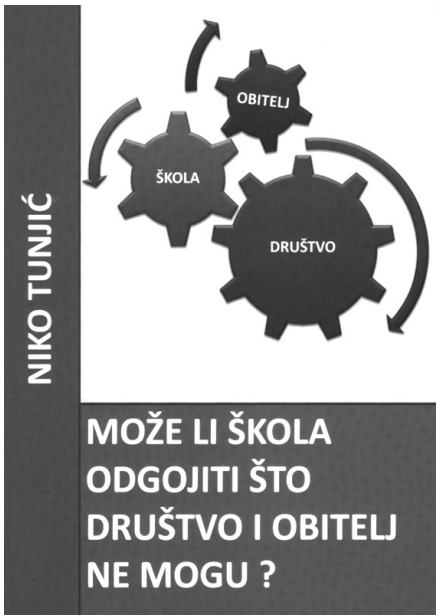

Odgoj kao fenomen nalazi se u domeni različitih subjekata. Odgoj je svojstven čovjeku, a na njega utječu brojni faktori, od kojih se posebice ističu: škola, obitelj i društvo. Upravo ti motivi postaju okosnica knjige naslova Može li škola odgojiti što društvo $i$ obitelj ne mogu? autora don Nike Tunjića. Autor je svećenik, salezijanac, teolog, magistar društvenih znanosti iz polja sociologije, doktor društvenih znanosti iz polja pedagogije i ravnatelj Salezijanske klasične gimnazije s pravom javnosti u Rijeci. Kao izniman stručnjak i praktičar s područja odgoja i obrazovanja objavio je pet knjiga, dva zbornika i nekolicinu članaka te ga možemo smatrati relevantnim autorom za današnji suvremeni kontekst odgoja i obrazovanja te školstva.

Knjiga je podijeljena u šest tematsko-sadržajnih cjelina: čovjek, djetinjstvo, mladi, sredstva javnog priopćavanja, žena te škola kao institucija. Tematika se obrađuje kroz ukupno devet poglavlja, od kojih su posljednja dva zaključak i bibliografija.

Uvod, iako tako naslovljen u knjizi, osim svojevrsne najave onog što knjiga u svojem sadržaju donosi, predstavlja jednu veoma kontekstualiziranu, obogaćenu, zaokruženu i zasebnu cjelinu. Uvod se bavi pitanjem čovjeka i njegovog određenja iz različitih perspektiva. Donosi filozofska, antropološka i teološka određenja čovjeka te ga promatra u kontekstu modernog društva i odgajateljskog poziva - kao tematske okosnice same knjige.

Poglavlje Naziv „djetinjstvo” - izazov za sve, sadržajno najkraće, objašnjava i kontekstualizira pojam djetinjstva. Predstavlja svojevrsni presjek određenih spoznaja dječje psihologije i povijesti djetinjstva u kontekstu kršćanstva i suvremenog doba. Time predstavlja uvod u iduće poglavlje koje se bavi mladima kao izazovom za odgajatelje. Autor ističe kako škola treba poticati cjelovit razvoj svakog djeteta da bi se ostvario mentalitet potpune vizije - pozitivnim upućivanjem na stvarnost u slobodi, 
samostalnosti, uzajamnosti, kompetenciji, u ambijentu u kojem se uči učiti misliti te znati i htjeti živjeti u zajedništvu.

Poglavlje Naziv „mladi” - izazov za odgajatelje donosi brojne spoznaje pedagogije i psihologije mladih, duhovnosti mladih, upoznaje s izazovima mladih u današnjem suvremenom društvu, mladima kao kulturom te tipologijom mladih (religijsko-duhovni, kritički nastrojeni, manirističko-postalternativni, orijentirani na tijelo i integrirani). Svi koji se na bilo koji način bave mladima ili su i sami mladi mogu u tom poglavlju pronaći upravo one osobitosti koje karakteriziraju mlade kao poseban identitet unutar društva. U poglavlju se prepoznaju promišljanja autora o životu mladih, a otkrivaju njegov dugogodišnji rad s mladima u odgoju i obrazovanju.

Uloga masounih medija $i$ društvo iduće je poglavlje koje se može označiti kao ono koje pripada medijskoj pedagogiji. Autor navodi vrste masovnih medija, analizira utjecaj i odnos djece te mladih i medija u suvremenom društvu, a na poseban način problematizira različite vrste tehnologije kao izazov za osobu, komunikaciju, odgoj i školu. Svakako se ističe postojanje potrebe za medijskom pedagogijom u današnjem globalnom društvu.

Iduće poglavlje naslovljeno je Naziv „žena” - izazov za odgoj, a prikazuje ulogu žene u različitim kontekstima, s posebnim naglaskom na njezinu ulogu u odgojnom djelovanju. Autor ženu karakterizira kao misaono i emocionalno biće, analizira je iz perspektive Biblije (Starog i Novog zavjeta) te dovodi do shvaćanja žene u kontekstu 21. stoljeća. U poglavlju se objašnjava i pokret žena, što upućuje na elemente feminističke pedagogije, nakon čega slijedi slika žene prema Ivanu Pavlu II. u dokumentu Muleris dignitatem. Naročito se opsežno obrađuje tematika ženskih škola. Naglasak je na vjerskim ženskim školama, a propituju se pitanja cilja odgoja i obrazovanja, pedagoška načela u radu, kao i konkretna pedagoška obilježja takvih škola. U posljednjem se dijelu poglavlja ženu predstavlja kao subjekt vlastitog bivstvovanja u svijetu i kao vođu koji mora imati svoj autoritet Autor ističe da je potrebna kritička revizija pojma autoriteta, nastojeći ga sagledati epistemološki kao „činiti da što raste“. Tako će žena biti ta koja će opravdati da je pravi autoritet onaj koji poštuje slobodu, želi biti poticajan, poštuje i vrednuje različitosti u postizanju zajedničkih ciljeva.

Početna se poglavlja bave različitim subjektima odgoja, a u petom se poglavlju obrađuje problematika škole u suvremenom društvu. Jedan od osnovnih problema jest pronalazak granice između škole i okoline te pitanje osobitosti školskog programa. U poglavlju se upoznaje kontekst političkog, gospodarskog i kulturnog razdora u svijetu, koji je ostavio utjecaj i na suvremenu školu. Međutim autor navodi kako je upravo škola zapravo pokretač suvremenosti, unutar prisutnih kontradiktornih međusobnih zahtjeva. U nastavku se obrađuje problematika škole kao institucije, školske autonomije, školske kulture i borbe za kontrolu škole (posebno od politike). U dijelu o postupnoj potvrdi školske zajednice autor promišlja o vjerskoj školi u ukupnom školskom kontekstu. Također, škola postaje kulturnim projektom u kojem su naglašene različite koncepcije kulture - svijest o nesvedivosti svakog 
kulturnog oblika na prirodan i spontan poredak, svijest o intersubjektivnosti smisla i potvrda, svijest o nerazdvojivosti sadržaja i metode te svijest o protjecanju vremena individualnih i kolektivnih nauka. Škola se stavlja u kognitivni, praktični, estetski i vjerski kontekst, nakon čega se upoznaje s preprekom koju konzumerističko društvo predstavlja prema suvremenoj školi. Iduća četiri poglavlja odnose se na odgojno djelovanje škole. Mjesto odgoja u školi, odgojne vrijednosti, povezanost škole i odgoja, školska disciplina kao način odgoja, psihologija razvoja odgoja u školi te način odgoja u školi samo su neke teme koje autor elaborira. Pritom je naročito istaknuto pitanje školske discipline, kojem pedagoška znanost daje premalo prostora. Posljednja dva poglavlja o suvremenoj školi odnose se na ulogu autoriteta u školi i ulogu ravnatelja kao vođe i koordinatora.

Posljednji sadržajni dio knjige naslovljen je Mjesto i uloga škole u društvu stalne evolucije. To je poglavlje obogaćeno različitim crtežima i slikama koje sadržaj nastoje obogatiti i približiti. U tom se dijelu obrađuju pitanja kvalitete, koncepata obrazovanja, važnosti misije i vizije škole te razvoj koherencije.

U zaključku knjige autor naglašava tri aspekta koja treba više razvijati u današnjem društvu i odgojno-obrazovnom sustavu, a to su: koncept cjeloživotnog učenja, autentično osnaživanje ravnatelja i europska dimenzija obrazovanja (sjećanje na kulturnu baštinu, svijest o etici sadašnjosti, provedba dobrih planova za budućnost radi očuvanja etičkih i duhovnih vrijednosti našeg zajedničkog nasljeđa, bolje obrazovanje građana, borba protiv socijalnih i ekonomskih razlika te suživot u zajedništvu).

Knjiga predstavlja vrijedan doprinos pedagoškoj teoriji i praksi, a u načinu obrade problematike ističe se nekoliko elemenata. Prije svega važno je naglasiti kako autor koristi spoznaje iz različitih područja pedagogije kao znanosti. Polazi od spoznaja povijesti odgoja i obrazovanja, povijesti djetinjstva, razvojne psihologije, obiteljske pedagogije, školske pedagogije, domske pedagogije, opće pedagogije, teorije odgoja, europske dimenzije u obrazovanju, feminističke pedagogije, pedagogije predškolskog odgoja, pedagogije mladih, školskog menadžmenta i religiozne pedagogije. Stoga bi se knjiga mogla nazvati svojevrsnim sažetkom osnovnih pedagoških koncepata, a kao takva može poslužiti i kao važna literatura u pedagoškom osposobljavanju budućih odgojno-obrazovnih djelatnika.

Međutim, koliko god to bila njezina velika prednost, moglo bi se reći da je to dovelo i do njezinog glavnog nedostatka. Naime knjizi nedostaje poveznica, nit vodilja u obradi sadržaja. Poglavlja su međusobno povezana time što obrađuju pitanja odgoja i obrazovanja. Međutim, osim navedene temeljne povezanosti, poglavlja nisu tematski i sadržajno povezana. To se može uočiti u načinu na koji se prelazi s jednog na drugo poglavlje. Primjerice, nakon poglavlja o mladima slijedi poglavlje o ženama, a potom poglavlje o školi. Poglavlja su prema strukturi više nalik na radove u zborniku nego na poglavlja knjige. Iako svako poglavlje obrađuje zasebnu temu, ne razabire se njihova sadržajna povezanost, kao ni kriterij određivanja slijeda poglavlja. Drugi se problem nadovezuje na prethodni, a odnosi se na naslov knjige. Naslov knjige upućuje na pomalo drugačiji sadržaj, navodi na očekivanje jasnijeg odgovora na postavljeno pitanje i navodi na pitanje o opravdanosti postavljanja takvog 
naslova. U prilog toj tezi ide i činjenica o nedostatku niti vodilje koja prati knjigu u svim njezinim poglavljima. Stoga knjiga više odgovara formi odabranih poglavlja iz pedagogije, što bi mogao biti dodatak naslovu knjige. Nije objašnjeno polazište na kojem počiva sam naslov: je li riječ o intervenciji škole nad onim što obitelj i društvo ne mogu, ne žele ili ne znaju; je li je riječ o onome što samo škola može, a obitelj i društvo po svojoj prirodi ne mogu ili nešto treće? Naslov upućuje na dodatni problem, a to je problematika obitelji. Iako je obitelj kao pojam obuhvaćena naslovom, problematika je obitelji nedovoljno obuhvaćena knjigom.

No valja se vratiti onom što knjiga uistinu pruža, a odgovara na pitanje iz naslova. Pedagozi bi na pitanje „Može li škola odgojiti što društvo i obitelj ne mogu?“ zasigurno odmah odgovorili kako je to moguće. Iako se knjiga samo u jednom poglavlju bavi školom na konkretniji način, vjerojatno nije za očekivati da će samo to poglavlje biti odgovor na pitanje iz naslova. Knjiga vrlo suptilno odgovara na to pitanje, predstavljajući cjelovitost odgoja, škola kao odgojna ustanova ponovno dobiva na važnosti.

Iznimna je vrijednost knjige u promišljanjima o odgoju. „Suputništvo kao odgoj je jedno od osnovnih ljudskih iskustava“ (str. 25). Prethodni citat dio je poglavlja 1.6. Covjek odgajatelj. Upravo je to poglavlje meni osobno najomiljenije, posebice u kontekstu vlastite profesije i poziva kao pedagoga. Iako je riječ o isključivo subjektivnoj perspektivi, ne može se zanijekati iskustvo i profesionalnost koji se očituju u tom poglavlju. Poglavlje postaje vodič odgajateljima, pedagozima, roditeljima i svima onima koji se na bilo koji način bave odgojem. Odgoju se u tom poglavlju daje kršćanska perspektiva, koja jasno ocrtava sve odgojne vrijednosti. Iako je danas malo stručne i praktične literature koja govori o domskom odgoju, sljedeća rečenica ocrtava jednu predivnu odgojiteljsku ulogu, primjenjivu za sve koji se bave odgojem: „Odgajateljska se ljubav, nadalje, pokazuje u dubokom prijateljstvu koje može razumjeti, pratiti, nuditi obogaćujući drugoga vlastitim iskustvom i dopuštajući vlastito obogaćenje očitovanjima Duha nazočnog u životu mladih" (str. 28). To je poglavlje vrelo predivnih misli o odgoju, uputa za odgojno djelovanje, prilika za iskustveno učenje i praktično djelovanje. To poglavlje, ako ne i čitava knjiga, zasigurno treba postati obaveznom literaturom na svim fakultetima koji se bave odgojem jer je u njemu sadržana srž odgojnog djelovanja, onog o kojem se toliko malo uči, a koje je neizostavan uvjet današnjeg čovjeka i društva.

Zaključak knjige donosi preporuke koje jesu važne i potrebne, ali ne proizlaze nužno iz samog sadržaja knjige, a to ukazuje na nepovezanost poglavlja i izostanak niti vodilje. Međutim, kada je riječ o zaključku, rečenica kojom knjiga završava glasi: „Obaveza je svih koji rade u školi i na svim razinama obrazovanja da izgrađuju mir i civilizaciju ljubavi“. Ljubav kao ljudska i kršćanska vrijednost, vrijednost koju je sv. Ivan don Bosco naglašavao u odgoju, vrijednost po kojoj smo svi ljudi jednaki jer nas povezuje. Mir kao unutarnja i vanjska dimenzija čovjeka, a civilizacija kao prilika i mogućnost, kao dokaz da škola ipak može odgojiti ono što društvo i obitelj ne mogu.

Da škola treba postati još jedno od središta odgojnog djelovanja, vjerojatno je jedan od ciljeva ove knjige. Knjiga u svakom svom dijelu u kojem je odgoj glavna tema 
naglašava njegovu važnost - posebice u suvremenom društvu. Postavljajući školu u odgojni kontekst, jasno pokazuje da odgoj vrijedi i za školsku perspektivu. Knjiga je uistinu relevantna u svojem sadržaju. Iako kao cjelina ima nedostataka u sistematizaciji i povezanosti, sadržaj je izuzetno pedagogiziran, suvremen i praktičan. Knjiga ocrtava nastojanje autora da se školu promišlja kao potencijal odgojnog djelovanja u današnjem društvu, posebice u kontekstu u kojem se uglavnom ističe obrazovna funkcija škole.

Filip Polegubić, magistar pedagogije Rijeka 